\title{
PENINGKATAN KEMAMPUAN KOGNITIF MELALUI \\ PERMAINAN TRADISIONAL ENGKLEK PADA \\ KELOMPOK A DI RA HIDAYATUL MUBTADIIN SIPRING \\ PAGELARAN-MALANG
}

\author{
Nur Laila ${ }^{1}$, Nurhayati ${ }^{2}$ \\ Program Studi Pendidikan Islam Anak Usia Dini,Fakultas Tarbiyah, \\ Institut Agama Islam Al-Qolam Malang \\ nurhayati@alqolam.ac.id
}

\section{Info Artikel}

Riwayat Artikel

Diterima :

1 September 2019

Disetujui :

30 September 2019
Kata Kunci :

Kemampuan Kognitif, Permainan Tradisional Engklek.

\section{ABSTRAK}

Abstract: The purpose of this research is to describe the traditional game of crank to improve children's cognitive abilities, to describe how to improve children's ability to recognize the symbol of children numbers 4-5 years old at $R A$ Hidayatul Mubtadiin Pagelaran. The research design used was Classroom Action Research using two cycles. Data collection techniques used observation, interviews and documentation. The results of the study were shown to have an increase in cognitive abilities in group A children at each cycle. The percentage of completeness data obtained $53.3 \%$ in cycle 1 , and is increasing at the end of cycle 2 that is equal to $86.6 \%$. Thus, an increase in the ability to recognize the symbol of numbers through the game of crickets in children aged 4-5 years from cycle 1 to cycle 2 with a difference of $33.3 \%$. Based on the results of data analysis, it was concluded that cognitive abilities had increased significantly. Seen from the final results states that the concept of traditional cricket game has the criteria of interest, ease and suitability in the learning process.

Abstrak: Penelitian ini tujuan untuk mendeskripsikan
permainan tradisional engklek dapat meningkatkan kemampuan
kognitif anak, untuk mendeskripsikan cara meningkatkan
kemampuan anak mengenal lambang bilangan anak usia 4-5
tahun di RA Hidayatul Mubtadiin Pagelaran. Rancangan
penelitian yang digunakan yaitu Penelitian Tindakan Kelas
dengan menggunkan dua siklus. Teknik pengumpulan data yang
digunakan observasi, wawancara dan dokumentasi. Hasil
penelitian yang ditunjukkan memiliki adanya peningkatan
kemampuan kognitif pada anak kelompok A pada setip siklus.
Data prosentase ketuntasan yang diperoleh 53,3\% pada siklus 1 ,
dan semakin meningkat pada akhir siklus 2 yakni sebesar $86,6 \%$.
Maka, peningkatan kemampuan mengenal lambang bilangan
melalui permainan engklek pada anak usia 4-5 tahun dari siklus
1 ke siklus 2 dengan selisish sebesar $33,3 \%$. Berdasarkan hasil
analisis data disimpulkan bahwa kemampuan kognitif meningkat
sangat signifikan. Terlihat dari hasil akhir menyatakan bahwa
konsep permainan trasidional engklek memiliki kriteria
ketertarikan, kemudahan dan kesesuaian dalam proses
pembelajaran.




\section{PENDAHULUAN}

Pendidikan Anak Usia Dini merupakan pendidikan yang sangat dasar dan menjadi masa keemasan (golden age) bagi anak. Undang-undang Republik Indonesia nomor 20 tahun 2003 tentang sistem pendidikan nasional, pasal 28 ayat $1^{1}$ berbunyi "Pendidikan anak usia dini diselenggarakan bagi anak sejak lahir sampai dengan enam tahun dan ini bukan merupakan persyaratan untuk mengikuti pendidikan dasar". Sehingga, pendidikan anak usia dini adalah suatu upaya pembinaan yang ditujukan kepada anak sejak lahir sampai dengan usia enam tahun yang dilakukan melalui pemberian rangsangan pendidikan untuk membantu pertumbuhan dan perkembangan jasmani dan rohani supaya anak memiliki kesiapan dalam memasuki pendidikan lebih lanjut.

Pada proses pendidikan diharapkan aspek perkembangan pada anak dapat berkembang sesuai dengan tahapan perkembangannya. Ada enam aspek yang harus dikembangkan pada anak usia dini meliputi aspek moral dan nilai agama, aspek kognitif, aspek fisik motorik, aspek bahasa, seni dan aspek sosial emosional ${ }^{2}$. Hal tersebut dapat mengembangkan aspek-aspek kemampuan dasar menjadi fondasi untuk melanjutkan ke tahap pendidikan selanjutnya.

Salah satu yang akan diamati oleh peneliti pada perkembangan kognitif anak. Hal tersebut di dukung dengan peraturan pemerintah nomor 58 tahun 2009 membahas tentang perkembangan kognitif anak usia dini di bagi menjadi tiga tahapan perkembangan sebagai indikator keberhasilan, meliputi pengetahuan umum dan sains, konsep bentuk dan warna, ukuran, dan pola serta konsep bilangan, lambang bilangan, dan huruf. ${ }^{3}$ Dimana, komponen-komponen pengembangan kemampuan kognitif pada anak menjadi salah satunya upaya pemberian rangsangan melalui aktivitas permainan-permainan tradisional secara bervariasi dan menyenangkan. Selain itu, perkembangan kemampuan kognitif akan memberikan pengaruh terhadap kesiapan mental meliputi sikap berfikir dan mengontrol sikap sosial dan emosional pada anak.

Strategi pembelajaran yang penting diterapkan kepada anak melalui sebuah konsep permainan ketika menyampaikan materi. Konsep permainan yang akan diterapkan dalam pembelajaran kognitif melalui permainan tradisional engklek. Permainan tradisional engklek merupakan permainan yang terkonsep secara berkelompok dengan menggunakan media berbentuk kecil menjadi simbol permainan engklek untuk di lempar pada bagian kotak-kotaknya. Sehingga, Permainan tersebut dapat menunjang perkembangan tingkat kemampuan kognitif anak dalam berhitung yang sesuai dengan tahap pencapaian pada kesesuaian materi yang ditentukan. Serta, memberikan nilai kebersamaan dalam bersosialisai antar teman sejawat pada saat permainan dilaksanakan secara berkelompok.

\footnotetext{
${ }^{1}$ Undang-undang Republik Indonesia Nomor 20 tahun 2003 tentang Sistem Pendidikan Nasional, pasal 28 ayat 1

${ }^{2}$ Suryadi dan Ulfah, (2013). Konsep Dasar Pendidikan Anak Usia Dini . Bandung : PT. Remaja Rodaskarya

${ }^{3}$ peraturan pemerintah nomor 58 tahun 2009
} 
Media merupakan alat bantu yang digunakan untuk mempermudah guru menyampaikan materi kepada anak didiknya. Selain itu dalam proses belajar mengajar media juga dapat membantu meningkatkan perkembangan kognitif anak. Selain perkembangan kognitif media juga dapat meningkatkan keempat aspek perkembangan yang lainnya yaitu perkembangan nilai-nilai dan moral agama, fisik motorik, bahasa, dan sosial emosional.

Berdasarkan hal tersebut dan dengan adanya pertumbuhan dan perkembangan anak usia dini yang memiliki ciri khas tersendiri, maka seorang pendidik anak usia dini perlu memahami prinsip-prinsip dan tahap perkembamgan anak usia dini. Pada anak usia 4 tahun ( usia pra sekolah ) perlu adanya bimbingan dan latihan agar anak siap mengikuti pendidikan berikutnya. Salah satu cara adalah dengan memberikan bimbingan kreativitas anak yaitu dengan memupuk imajinasi anak dengan berbagai pengalaman langsung yng di alami oleh anak dan hal tersebut akan terkesan bagi anak yang sangat mempengaruhi pertumbuhan dan perkembangan jiwa anak lebih lanjut. Untuk itu pada pendidikan pra sekolah, hendaknya anak diberikan kesempatan untuk berkreasi dengan berbagai cara dan media yang menarik bagi anak.

Berdasarkan pengamatan terhadap kegiatan pengembangan di kelas di temukan adanya masalah rendahnya kemampuan mengenal kognitif anak yang di tandai dengan beberapa kondisi berikut. Pertama, setiap anak diberi kesempatan maju kedepan untuk mengenal lambang bilangan ternyata hanya 4 dari 15 anak dikelompok A. Kedua, ketika beberapa anak yang telah lebih dahulu menyelesaikan kegiatan diberikan kesempatan untuk bermain bebas, 6 anak memilih untuk tidak mau maju kedepan, sisanya memilih untuk bermain di luar ruangan, jarang sekali anak yang mau mengikuti pelajaran berhitung atau pada waktu mengenal lambang bilangan. Ketiga, saat kegiatan berhitung atau mengenal lambang bilangan hanya beberapa anak saja yang aktif sampai akhir kegiatan. Keempat, guru masih kurang memberi stimulasi kegiatan berhitung atau mengenal lambang bilangan kepada anak.

Proses perkembangan anak perlu adanya pembina secara kreatif melalui pengenalan, pembiasaan, dan latihan-latihan pada kegiatan berkreasi anak RA/BA/TA juga akan merasa bosan dan jenuh bila kegiatan tersebut dilakukan berulang-ulang dalam kegiatan mengenal lambang bilangan dengan cara menulis, membaca, mewarnai angka. Hal ini berdasarkan pengalaman penulis pada saat dilakukannya kegiatan mengenal lambang bilangan dengan menulis angka dan membaca angka dikelompok A Hidayatul Mubtadiin Sipring Pagelaran Kab.Malang, pada waktu saya melakukan observasi, saya menemukan data yaitu sebagai berikut. Pertama dari 15 anak hanya 4 anak yang bersemangat untuk menulis dan membaca lambang bilangan sampai seelesai. Kedua anak merasa bosan dan tidak mau menyelesaikan kegiatan tersebut sampai selesai. Ketiga sebagian anak masih merasa malas untuk mengikuti kegiatan tersebut. Jadi dengan diadakannya penelitian yang menggunakan permainan tradisional engklek sebagai 
media utama dalam mengenal lambang bilangan ini diharapkan anak dapat belajar sambil bermain sehingga anak tidak merasa bosan dan mau menyelesaikan kegiatan sampai selesai.

Berdasarkan paparan di atas penyebab masalah pengembangan di kelas yaitu. Pertama kurangnya media pembelajaran yang bervariatif. Kedua guru kurang kreatif dalam menciptakan metode-metode pembelajaran yang sesuai dengan perkembangan anak. Ketiga kurangnya beragam kegiatan sehingga anak merasa kurang minat untuk mengikuti pembelajaran tersebut.

Tujuan yang ingin di capai dalam penelitian ini pertama, untuk mendiskripsikan permainan tradisional Engklek dapat meningkatkan kemampuan Kognitif. Kedua, untuk mendeskisikan cara meningkatkan kemampuan anak mengenal lambang bilangan melalui permaina tradisional engklek. anak kelompok A di RA Hidayatul Mubtadiin.

\section{METODE PENELITIAN}

Penelitian ini menggunakan rancangan penelitian tindakan kelas (PTK) melalui pendekatan tindakan penelitian (action research) yang dilaksanakan oleh guru didalam kelas. penelitian tindakan pada hakikatnya merupakan rangkaian "riset-tindakan riset-tindakan" yang dilakukan secara siklis dalam rangka memecahkan masalah, sampai masalah itu terpecahkan. Penelitian Tindakan Kelas (PTK) adalah suatu bentuk kajian yang bersifat sistematis, oleh karena itu penelitian tindakalan kelas ini merupakan salah satu pendekatan penelitian ilmiyah yang mempunyai dua tujuan yaitu mengambil tindakan (untuk perbaikan) dan membangun pengetahuan atau teori tentang tindankan. Menurut Kemmis dan Taggart (dalam sugiyono, 2014) mengatakan bahwa proses daur ulang dalam kegiatan penelitian tindakan yaitu berbentuk spiral dari siklus I ke siklus berikutnya yakni siklus II, diawali dengan perencanaan tindakan (planning), pelaksanaan tindakan (action), mengobservasi dan mengevaluasi proses dan hasil tindakan (observation and evaluation), serta melakukan refleksi (reflection), kemudian berputar sampai terjadi perbaikan atau peningkatanyang di harapkan (sesuai dengan kriteria pencapaian tujuan penelitian). ${ }^{4}$

Model PTK yang dilakaukan penelitian ini adalah penelitian kelas kolaboratif dimana diperlukannya kerja sama dengan pihak-pihak lain seperti atasan atau teman sejawat misalnya. Mengapa demikian karena ada hakikatnya kedudukan penelitian dalam PTK merupakan sumber dari bagian situasi dan kondisi dari suatu latar yang ditelitinya. ${ }^{5}$ Situasi pada lokasi penelitian ini di laksanakan di RA Hidayatul Mubtadiin Sipring terletak di desa Pagelaran tepatnya di J1. Sawunggaling No.02 RT.01 RW.01 dusun Sipring desa Pagelaran kecamatan

\footnotetext{
${ }^{4}$ Sugiyono, (2014). Metode Penelitian Kuantitatif, Kualitatif, dan $R \& D$. Bandung: Alfabeta.

${ }^{5}$ Ismanto,. S \& Daryanto. (2007) Panduan Praktis Penelitian Ilmiah. Yokyakarta : Penerbit Gava Media.
} 
Pagelaran kabupaten Malang. Lembang RA tersebut menjadi satu yayasan dengan MI.

Dalam penelitian ini, peneliti dalam melakukan pengamatan dan pengumpulan data menggunakan instrument penilaian, instrument pengumpul data harus sesuai dengan tujuan perbaikan yang di rancang, karena ketercapaian tujuan inilah yang menjadi fokus pengumpulan data. Maka selama penelitian ini, peneliti menggunakan instrument penilaian berupa obsevasi dan dokumentasi yang di jabarkan meliputi tehnik observasi, wawancara, dan dokumentasi ${ }^{6}$

Tahap selanjutnya ketika teknik pengumpulan data sudah di peroleh, peneliti menyelesaikan analisis data untuk mengetahui keberhasil atau tidaknya tindakan yang dilakukan untuk mendiskripsikan peningkatan kemampuan kognitif anak. Tindakan dalam penelitian ini dinyatakan berhasil jika di peningkatan kognitif melalui permainan tradisional engklek $75 \%$ dari 15 anak kelompok A di RA Hidayatul Mubtadiin mengalami peningkatan mengenal lambang bilangan pada kriteria berkembang sangat baik (BSB).

\section{HASIL DAN PEMBAHASAN}

Pada hasil siklus 1 pembelajaran menggunakan pendekatan menciptakan kegiatan yang kreatif dan inovatif. Hal ini sesuai dengan belajar anak. Tujuannya adalah ketika proses pembelajaran berlangsung diharapkan dapat tercipta suasana belajar yang menyenangkan. kegiatan pengembangan dalam siklus 1 ini sudah relevan dengan RPPH yang telah dibuat. Anak mulai antusias dan senang dalam mengenal lambang bilangan, anak mulai dapat memahami lambang bilangan dasar, anak dapat juga dapat memahami lambang bilangan dengan tepat dan benar, meskipun hasilnya belum maksimal sesuai yang diharapkan. Karena hanya ada beberapa anak yang dapat mengenal lambang bilangan dengan tepat dan benar.

Berdasarkan rekapitulasi penilaian dalam kegiatan pelaksanaan pengembangan siklus 1 ini, di temukan adanya peningkatan kemampuan mengenal lambang bilangan 53,3\% ( 9 dari 15 siswa yang ada ). Berdasarkan data tersebut, maka peningkatan kemampuan anak dalam mengenal lambang bilangan belum berhasil dengan maksimal. Maka, kegiatan yang belum tercapai dalam siklus 1 ini akan ditingkatkan dalam siklus berikutnya ( siklus 2 ).

Pada hasil siklus 2 pembelajaran menggunakan pendekatan yang sama dengan siklus 1, yaitu menciptakan kegiatan yang kreatif dan inovatif. Hal ini sesuai dengan belajar anak. Tujuannya adalah ketika proses pembelajaran berlangsung diharapkan dapat tercipta suasana belajar yang menyenangkan dan keterlibatan anak secara kreatif dan inovatif. Kegiatan pengembangan dalam siklus 2 ini sudah relevan dengan RPPH yang telah dibuat. Anak semakin antusias dan senang dalam mengenal lambang bilangan, karena dalam siklus 2 ini media yang digunakan anak bervariasi. Untuk membuat anak tidak bosan dengan kegiatan yang sama, guru (

${ }^{6}$ Ekawarna. (2011). Penelitian Tindakan Kelas, Cetakan kedua. Jakarta : GP Press. 
peneliti ) juga menambahkan variasi kegiatan berupa permainan tradisional engklek. Anak mulai dapat memahami lambang bilangan dasar, anak dapat juga dapat memahami lambang bilangan dengan tepat dan benar, hasilnya sudah maksimal sesuai yang diharapkan.

Berdasarkan rekapitulasi penilaian dalam kegiatan pelaksanaan pengembangan siklus 2 ini, di temukan adanya peningkatan kemampuan mengenal lambang bilangan di bandingkan sebelum pelaksanaan siklus 1. Sebelum pelaksanaan siklus 1, prosentase ketuntasan belajar anak dalam mengenal lambang bilangan hanya sebesar 53,3 \% ( 8 dari 15 siswa yang ada ). Setelah pelaksanaan siklus 2, prosentase ketuntasan belajar anak dalam mengenal lambang bilangan sebesar 86,6 \% ( 13 dari 15 siswa yang ada ). Berdasarkan data tersebut, maka peningkatan kemampuan anak dalam mengenal lambang bilangan dari pelaksanaan siklus 1 sampai akhir siklus 2 sebesar $21,7 \%$.

Hasil data tersebut, dapat disimpulkan bahwa kemampuan mengenal lambang bilangan pada anak 4-5 tahun melalui permainan tradisional engklek ini dalam siklus 2 ini telah berhasil. Peningkatan Kemampuan Kognitif melalui permainan tradisional engklek ditentukan dengan pemerolehan hasil yang telah dicapai pada siklus 1 dan siklus 2, dapat disimpulkan bahwa kemampuan mengenal lambang bilangan anak pada usia 4-5 tahun melalui permainan engklek telah mengalami peningkatan yang signifikan. Anak semakin suka saat kegiatan mengenal lambang bilangan, pada usia 3 sampai 4 tahun, anak pra sekolah sudah bisa memanipulasi lingkungan dan senang menemukan hal-hal baru. Mereka mulai menggeneralisasi satu situasi ke situasi lain.

Data awal yang diperoleh dengan ketuntasan belajar sebesar 3,75\% dapat meningkat sebesar 53,3\% pada siklus 1 , dan semakin meningkat pada akhir siklus 2 yakni sebesar $86,6 \%$. Maka, peningkatan kemampuan mengenal lambang bilangan melalui gambar pada anak usia 4-5 tahun dari siklus 1 ke siklus 2 sebesar $33,3 \%$. Hal ini dapat digambarkan dalam table sebagai berikut:

Table 4.12 Peningkatan Kemampuan Mengenal Lambang Bilangan Siklus 1 dan Siklus $2^{7}$

\begin{tabular}{cccc}
\hline No & Siklus & Hasil ( \%) & Posentase Peningkatan \\
\hline $\mathbf{1}$ & Siklus 1 & $53,3 \%$ & Selisih \\
\hline $\mathbf{2}$ & Siklus 2 & $86,6 \%$ & $53,3 \%-86,6 \%=33,3 \%$ \\
\hline \multicolumn{4}{r}{ Adapun digambarkan dalam bentuk diagram, maka hasilnya akan tampak }
\end{tabular}

pada diagram peningkatan kemampuan mengenal lambang bilangan dalam proses kemampuan anak usia dini. Tabel 4.1, sebagai berikut:

${ }^{7}$ Table 4.12 Peningkatan Kemampuan Mengenal Lambang Bilangan Siklus 1 dan Siklus 2 


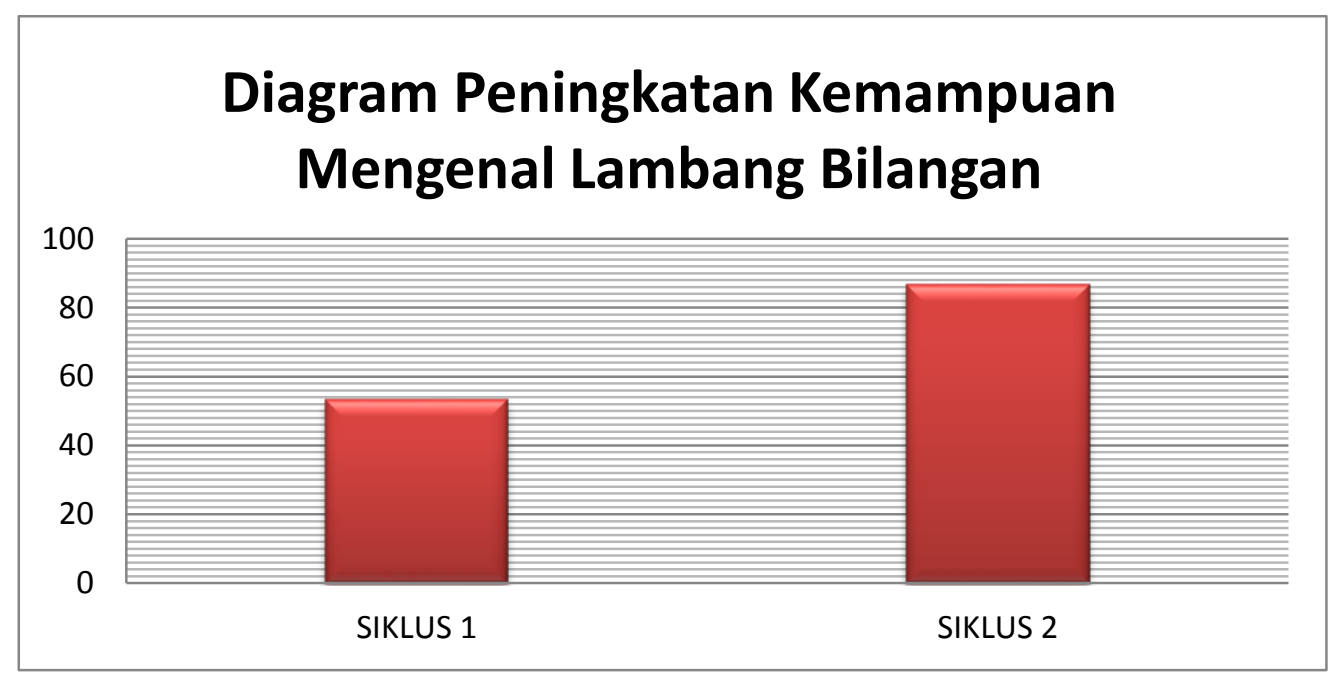

Gambar 4.1 Diagram peningkatan kemampuan mengenal lambang bilangan siklus 1 dan siklus 2

Pada siklus 1, prosentase peningkatan kemampuan mengenal lambang bilangan sebesar 53,3\%, dan meningkat pada siklus 2 yakni sebesar 86,6\%. Dengan selisih peningkatan $33,3 \%$. Sehingga, peningkatan kemampuan kognitif dengan pembelajaran mengenal lambang bilang melalui konsep permainan engklek sangat efektif. Keefektifan yang dihasilkan terlihat dari hasil akhir prosentase dari siklus I dan siklus II sebesar 33,3\% termasuk kategori sedang. Dimana, tingkat kemampuan anak sangat berkembangan sesuai dengan indikator keberhasilan yang telah ditentukan. Sehingga, alternatif konsep pembelajaran melalui permainan tradisional engklek menjadi kunci dalam mengembangkan aspek kemampuan terutama pada kemampuan kognitif anak usia dini.

\section{SIMPULAN DAN SARAN}

Hasil perhitungan analisis data yang telah dicapai pada siklus I dan siklus II, dapat disimpulkan bahwa kemampuan mengenal lambang bilangan anak pada usia 4-5 tahun melalui permainan tradisional engklek telah mengalami peningkatan sangat baik. Data awal yang diperoleh dengan ketuntasan belajar sebesar 3,75\% dapat meningkat sebesar 53,3\% pada siklus I, dan semakin meningkat pada akhir siklus II yakni sebesar $86,6 \%$. Maka, peningkatan kemampuan mengenal lambang bilangan melalui permainan tradisional engklek pada anak usia 4-5 tahun dari siklus I ke siklus II sebesar 33,3\%.

Berdasarkan kesimpulan hasil penelitian terdapat saran untuk dapat di gunakan. Pertama, bagi guru, guru Raudlatul Athfal diharapkan terus mengikuti perkembangan zaman sehingga pendidikan anak usia dini bisa meningkatkan kualitas anak dalam belajar. Kegiatan mengenal lambang bilangan dengan beberapa metode yang berbeda sehingga anak tidak merasa bosan,tidak hanya perkembangan kognitif saja melainkan semua aspek perkembangan anak usia dini. Kedua, bagi kepala sekolah, untuk meningkatkan kemampuan kognitif anak tentang lambang bilangan. Hendaknya kepala sekolah mengadakan sosialisasi dengan para guru dan 
menerapkan kegiatan pembelajaran berupa permainan tradisional yang beragam atau melalui penambahan sarana prasarana sekolah. Ketiga, bagi orang tua anak didik, agar peningkatan kemampuan kognitif dapat lebih optimal maka alangkah baiknya apabila orang tua memberikan motivasi dan memantau perkembangan belajar anak-anaknya ketika di rumah. Keempat, bagi peneliti, masukan bagi peneliti lanjut, untuk meningkatkan aktivitas permainan tradisional engklek untuk diterapkan dalam kemampuan aspek berkembangan lainnya. Agar lebih terlihat peningkatannya dan kebermanfaatannya pada pendidikan anak usia dini.

\section{DAFTAR RUJUKAN}

Suryadi dan Ulfah, (2013). Konsep Dasar Pendidikan Anak Usia Dini . Bandung : PT. Remaja Rodaskarya

Ekawarna. (2011). Penelitian Tindakan Kelas, Cetakan kedua. Jakarta : GP Press.

Ismanto,. S \& Daryanto. (2007) Panduan Praktis Penelitian Ilmiah. Yokyakarta : Penerbit Gava Media.

Sugiyono, (2014). Metode Penelitian Kuantitatif, Kualitatif, dan R\&D. Bandung : Alfabeta. 